\title{
SS-081 学校におけるリスク・マネジメント教育一必要か、可能か? -
}

\author{
企画代表者: 吉川 肇子 (慶應義塾大学) \\ 話題提供者：西田 公昭 (立正大学) \\ 話題提供者: 三浦 麻子 (関西学院大学) \\ 話題提供者: 杉浦 淳吉 (慶應義塾大学) \\ 指定討論者: 大坊 郁夫 (東京未来大学)
}

本シンポジウムでは、大学におけるリスク・マネジメント教育の必要性と可能性について、話題提供と 議論を行う。まず、大学生に対して必要なリスク・マネジメント教育について、個別の分野をとりあげ てその必要性を議論する。すべての分野を取りあげることはできないが、主に以下の分野を中心に話題 提供する。（1）カルトのリスク、（2）ネットのリスク、（3）消費生活のリスク。次に、これらの問題に 対して、どのような教育が可能かをフロアとともに議論したい。論点は 2 つる。（1）試行錯誤や失敗 を通して学べるリスクと、あらかじめ回避しておくべきリスクがあるかどうか。もし後者があるとする なら、教育は必要であろうが、具体的にそれらはどういうリスクか。(2) 心理学専攻の学生がリスク ・ マネジメントを学ぶことの優位性。基礎的な分野の知見を、どのようにこの教育に活かしていけるのか、 教材の紹介とともに議論したい。 